\title{
Penerapan Sistem Informasi Akuntansi Persediaan Bahan Baku Pada PT Pupuk Sriwidjaja (Persero) Palembang
}

\author{
Panca Satria Putra ${ }^{1}$, Mohamad Nur Arriyanto ${ }^{2}$, Sophie Wahyuni ${ }^{3}$ \\ ${ }^{1}$ Fakultas Ekonomi dan Bisnis Universitas PGRI Palembang, pancadahlan1@gmaiil.com \\ ${ }^{2}$ Fakultas Ekonomi dan Bisnis Universitas PGRI Palembang, arriyanto.m.nur@gmail.com \\ ${ }^{3}$ Fakultas Ekonomi dan Bisnis Universitas PGRI Palembang, sofhiewahyuni48@gmail.com
}

\begin{abstract}
This study aims to find out how the accounting system for raw material inventory information is implemented by PT Pupuk Sriwidjaja (Persero) Palembang.The method used is qualitative, the sample in this study is Accounting Information System for Raw Material Inventory of PT Pupuk Sriwidjaja (Persero) Palembang in 2017-2019, the source of the data in this study is secondary data, data collection techniques used are literature study, observation and documentation. The data analysis technique used is descriptive qualitative.Based on the results of the analysis, the analysis used is to compare the accounting information system of raw material inventory at PT Pupuk Sriwidjaja (Persero) Palembang with theories so that conclusions can be drawn. As for the results of the research that the author has done, the results are obtained that the accounting information system for raw material inventory at PT Pupuk Sriwidjaja (Persero) Palembang is adequate with the integrated SAP system. In 2017 the achievement of 89,520 TON of NPK fertilizer raw material, in 2018 the achievement of 104,578 TON of NPK fertilizer, and in 2019 the achievement of 103,338 TON of NPK fertilizer.
\end{abstract}

Keywords: Accounting information systems, raw material inventory

\begin{abstract}
ABSTRAK
Penelitian ini bertujuan untuk mengetahui bagaimanakah sistem informasi akuntansi persediaan bahan baku yang diterapkan oleh PT Pupuk Sriwidjaja (Persero) Palembang.Metode yang digunakan kualitatif, sampel dalam penelitian ini Sistem Informasi Akuntansi Persediaan Bahan Baku PT Pupuk Sriwidjaja (Persero) Palembang tahun 2017-2019, sumber data dalam penelitian ini adalah data sekunder, teknik pengumpulan data yang digunakan adalah studi kepustakaan, observasi, dan dokumentasi. Teknik analisis data yang digunakan adalah deskriptif kualitatif. Berdasarkan hasil analisis adapun analisis yang digunakan yaitu membandingkan sistem informasi akuntansi persediaan bahan baku pada PT Pupuk Sriwidjaja (Persero) Palembang dengan teori-teori sehingga dapat ditarik kesimpulan. Adapun hasil penelitian yang penulis telah lakukan, maka didapatkan hasil bahwa sistem informasi akuntansi persediaan bahan baku pada PT Pupuk Sriwidjaja (Persero) Palembang telah memadai dengan sistem SAP yang telah terintegrasi. Pada tahun 2017 pencapaian bahan baku pupuk NPK sebanyak 89.520 TON, pada tahun 2018 pencapaian bahan baku pupuk NPK sebanyak 104.578 TON, dan pada tahun 2019 pencapaian bahan baku pupuk NPK sebanyak 103.338 TON.
\end{abstract}

Kata Kunci: Sistem informasi akuntansi, persediaan bahan baku

\section{A. PENDAHULUAN}

Telah diketahui bahwa informasi merupakan salah satu sumber daya yang sangat diperlukan bagi manajemen dalam pengambilan keputusan. Untuk mendapatkan informasi tersebut perlu adanya sebuah sistem yang mengolah data menjadi sebuah sistem informasi yang berharga. Sistem tersebut disebut dengan information processing system atau lebih dikenal dengan sistem informasi. Siste informasi sendiri dapat dibedakan menjadi dua yaitu sistem informasi manual dan sistem informasi berbasis komputer. Sistem informasi berbasis komputer merupakan suatu sistem pengolahan data menjadi informasi dengan menggunakan alat bantu pengambilan keputusan. Dalam sistem informasi akuntansi berbasis komputer ini 
memiliki arti bahwa komputer mempunyai peranan yang sangat penting di dalam sebuah sistem informasi akuntansi tersebut.

Sistem Informasi merupakan hal yang penting dalam suatu perusahaan, dimana perusahaan bisnis saati ini semakin berlomba-lomba untuk menciptakan dan meningkatkan kualitas kerja, mutu pelayanan dan keakuratan data guna menghadapi persaiangan bisnis yang semakin ketat. Sistem informasi sendiri memiliki pengertian yaitu seperangkat unsur yang secara teratur saling berkaitan sehingga membentuk suatu totalitas yang berupa informasi.

Setiap perusahaan memiliki kebutuhan akan informasi yang berbeda-beda karena sistem informasi yang ada seperti sistem informasi akuntansi arus kas, sistem informasi pemasaran, sistem informasi akuntansi persediaan, sistem informasi produksi tidak dapat diterapkan disemua jenis perusahaan. Perusahaan yang bergerak dibidang jasa konsul tidak membutuhkan sistem informasi akuntansi persediaan karena perusahaan tersebut tidak melakukan proses penghitungan persediaan.

Persediaan adalah bagian-bagian yang disediakan dan bahan-bahan dalam proses yang terdapat dalam perusahaan untuk proses produksi, serta barang-barang jadi/produk yang disediakan untuk memenuhi permintaan dari konsumen atau pelanggan setiap waktu (Rangkuti, 2018:1).

Bahan baku merupakan bahan-bahan yang menjadi komponen utama untuk membentuk keseluruhan dari produk jadi (Sujarweni, 2015:27). Persediaan bahan baku adalah barang-barang yang diperoleh dalam keadaan harus dikembangkan yang akan menjadi bagian utama dari barang jadi atau barang-barang berwujud yang diperoleh untuk penggunaan langsung dalam proses produksi sedang persediaan barang dalam proses, meliputi produk-produk yang telah mulai dimasukkan dalam proses produksi, namun belum selesai diolah sedangkan persediaan barang jadi meliputi produk-produk olahan yang siap untuk dijual kepada para konsumen.

Setiap perusahaan, apakah itu perusahaan dagang ataupun manufaktur selalu mengadakan persediaan, tanpa adanya persediaan yang optimal para pengusaha akan dihadapkan pada resiko bahwa perusahaannya pada suatu waktu tidak dapat memenuhi keinginan konsumen yang memerlukan atau meminta produk yang dihasilkan. Hal ini mungkin terjadi, karena tidak selamanya pupuk tersedia pada setiap saat yang berarti pula bahwa perusahaan akan kehilangan kesempatan memperoleh keuntungan yang seharusnya didapatkan.

Perusahaan sebaiknya selalu menyediakan bahan baku yang akan diolah untuk proses produksinya agar tidak menghambat kelancaran usaha. Persediaan merupakan bagian utama dari modal kerja yang merupakan aktiva yang pada setiap saat mengalami perubahan. Semakin tinggi atau semakin cepat tingkat perputaran persediaan berarti semakin cepat tingkat perputaran persediaan berarti semakin pendek tingkat dana dalam persediaan sehingga dibutuhkan dana yang relatif kecil.

Sebaliknya semakin rendah atau semakin lambat tingkat perputaran persediaan berarti semakin panjang terikatnya dana dalam persediaan. Pada perusahaan manufaktur, masalah yang sering dihadapi adalah masalah kelancaran proses produksi berupa penangganan persediaan bahan baku yang tepat agar tidak terjadi kelebihan serta kekurangan bahan baku, perusahaan harus dapat mengelola persediaan yang dimiliki sebaik mungkin sesuai dengan kebijakan-kebijakan manajemen perusahaan.

Penerapan sistem informasi akuntansi pada PT Pupuk Sriwidjaja (Persero) Palembang sudah diterapkan dari tahun 2002 sampai sekarang. Adapun untuk 
sistem informasi akuntansi persediaan bahan bakunya tidak selalu sama dari tahun 2002 hingga tahun 2015 menggunakan sistem IFS (Industrial and Financial System). Dan dari tahub 2016 sampai sekarang Pusri menggunakan SAP (System Analysis and Product in Data Processing).

Berdasarkan penelitian terdahulu yang diteliti oleh Harianto (2018:42) menunjukkan hasil sistem akuntansi persediaan bahan baku pada PT. Perkebunan Nusantara IV (Persero) Medan masih kurang memadai dimana perusahaan masih menggunakan sistem yang manual, yang mana proses sistem informasi akuntansi manual ini sedikit lebih lambat dibandingkan yang terkomputerisasi.

\section{B. KAJIAN TEORI}

\section{Sistem Informasi Akuntansi}

Andi (2015:2) sistem informasi akuntansi merupakan sistem yang menyediakan informasi akuntansi dan keuangan beserta informasi lainnya yang diperoleh dari proses rutin transaksi akuntansi.

Marshall B. Romney dan Paul John Steinbart (2015:11) akuntansi adalah proses identifikasi, pengumpulan, dan penyimpanan data serta proses pengembangan, pengukuran, dan komunikasi informasi. Berdasarkan definisi tersebut, akuntansi adalah sistem informasi karena SIA mengumpulkan, mencatat, menyimpan, dan memproses akuntansi dan data lain untuk menghasilkan informasi bagi pembuat keputusan.

\section{Tujuan Sistem Informasi Akuntansi}

1. Untuk menyediakan Informasi Bagi Usaha Baru

Kebutuhan informasi pada usaha baru sangat penting untuk mampu bersaing dalam dunia usaha.

2. Untuk memperbaiki informasi yang dihasilkan dari sistem yang sudah ada atau sistem lama. Dalam perusahaan yang baru berjalan sangat dibutuhkan pengembangan sistem akuntansi.

3. Untuk memperbaiki sistem pengendalian intern perusahaan sehingga dapat mempermudah menjaga kekayaan perusahaan.

4. Untuk mengurangi biaya kegiatan klerikal dalam kegiatan akuntansi. Dalam hal ini informasi dapat dijadikan sebagai barang ekonomi yang mempunyai banyak manfaat, karena untuk memperolehnya diperlukan pengorbanan sumber ekonomi lainnya.

\section{Persediaan}

Freddy Rangkuti (2018:1) pengertian mengenai persediaan dalam hal ini adalah sebagai suatu aktiva yang meliputi barang-barang milik perusahaan dengan maksud untuk dijual dalam suatu periode usaha tertentu, atau persediaan barang-barang yang masih dalam pengerjaan/proses produksi, ataupun persediaan bahan baku yang menunggu penggunaannya dalam suatu proses produksi.

\section{Fungsi Persediaan}

Menurut Freddy Rangkuti (2018:15) fungsi-fungsi persediaan adalah sebagai berikut:

\section{Fungsi Decoupling}

Adalah persediaan yang memungkinkan perusahaan dapat memenuhi permintaan langgananan tanpa tergantung pada supplier.

2. Fungsi Economic Lot Sizing 
Persediaan lot size ini perlu mempertimbangkan penghematan-penghematan atau portongan pembelian, biaya pengangkutan per unit menjadi lebih murah dan sebagainya.

3. Fungsi Antisipasi

Apabila perusahaan menghadapi fluktuasi permintaan yang dapat diperkirakan dan diramalkan berdasarkan pengalaman atau data-data masa lalu, yaitu permintaan musiman. Dalam hal ini perusahaan dapat mengadakan persediaan musiman.

\section{Biaya Persediaan}

Untuk pengambilan keputusan penentuan besarnya jumlah persediaan, biayabiaya variabel berikut ini harus dipertimbangkan.

1. Biaya penyimpanan, yaitu biaya yang timbul karena perusahaan menyimpan persediaan. Biaya ini meliputi: bunga atas investasi, asuransi, pajak, penyusutan, kerusakan produk/barang, sewa gudang, penurunan harga.

2. Biaya pemesanan, yaitu biaya yang berhubungan dengan pemesanan dan pengadaan bahan. Tetapi kalau sifatnya produksi maka biaya pengadaan disebut setup cost yang meliputi biaya yang diperlukan untuk proses produksi seperti perbaikan mesin, penambahan mesin baru, mendapatkan bahan baku, dan memperoleh tenaga kerja.

3. Biaya stock-out cost, yaitu biaya yang timbul akibat perusahaan kehabisan persediaan. Kalau pelanggan mau menunggu, maka biaya terdiri dari ongkos produksi yang terburu-buru. Tetapi kalau pelanggan tidak rela menunggu, maka biaya terdiri dari kehilangan kepercayaan.

\section{Metode Pencatatan Persediaan}

1. Economic Order Quantity (EOQ)

Ahmad (2018:175) Economic Order Quantity (EOQ) atau Economic Lot Size (ELS) adalah suatu metode manajemen persediaan yang paling terkenal dan paling tua sejak 1914 yang dikenalkan oleh FW. Haris. Martono (2010:85) rumus EOQ :

$$
\mathrm{EOQ}=\sqrt{\frac{\sqrt{2 x R x S}}{P x I}}
$$

\section{Recorder Point (ROP)}

Menurut Ahmad (2018:175) titik pemesanan ulang adalah titik waktu dimana pesanan baru harus dilakukan. Waktu tunggu Ahmad (2018:175) adalah waktu yang diperlukan untuk menerima kuantitas pesanan ekonomi ketika pesanan dilakukan. Martono (2010: 88) Recorder Point dihitung dengan rumus perhitungan:

$$
\mathrm{RoP}=(\mathrm{LT} \times \mathrm{AU})+\mathrm{SS}
$$

\section{Safety Stock (SS)}

Ahmad (2018:176) persediaan pengamanan (safety stock) adalah persediaan ekstra yang disimpan sebagai jaminan dalam menghadapi permintaan yang berfluktasi. Martono (2010:88) Safety Stock dihitung dengan rumus:

$$
\text { Pemakaian Maksimum - Pemakaian rata-rata }
$$




\section{Penentu Harga Pokok Persediaan}

Penentuan harga pokok persediaan sangat tergantung dari metode penilaian yang dipakai diantaranya:

\section{Metode First-In First-Out (FIFO)}

Metode ini dipakai berdasarkan asumsi bahwa perhitungan harga pokok didasarkan atas urutan pembelian barang tersebut.

2. Metode Last-In First-Out (LIFO)

Metode ini didasarkan pada asumsi bahwa himpunan harga pokok yang terakhir akan dibebankan sebagai harga barang yang dijual, dengan demikia nilai persediaan yang akan disajikan pada neraca merupakan cost yang berasal dari pembelian-pembelian yang pertama.

3. Metode Harga Pokok Rata-rata

Perhitungan harga pokok didasarkan atas harga rata-rata tertimbang per unit dari barang yang dijual.

\section{Pengertian Bahan Baku}

Sujarweni (2015: 27-28) bahan baku adalah: “ Bahan baku sendiri mempunyai definisi bahan-bahan yang merupakan komponen utama yang membentuk keseluruhan dari produk jadi".

1. Penerimaan bahan baku

Adalah diterimanya barang digudang Area. Bahan baku dapat berasal dari gudang unit administrasi lain, dari pesanan kepada rekanan/supplier, atau karena sisa pemakaian suatu pekerjaan.

2. Pengeluaran bahan baku

Adalah proses keluarnya bahan baku dari gudang Area. Pengeluaran bahan baku dapat disebabkan oleh permintaan dari gudang unit administrasi lain, dari unit internal dalam rangka pelaksanaan pekerjaan yang bersifat investasi maupun operasional.

\section{Kerangka Pemikiran}

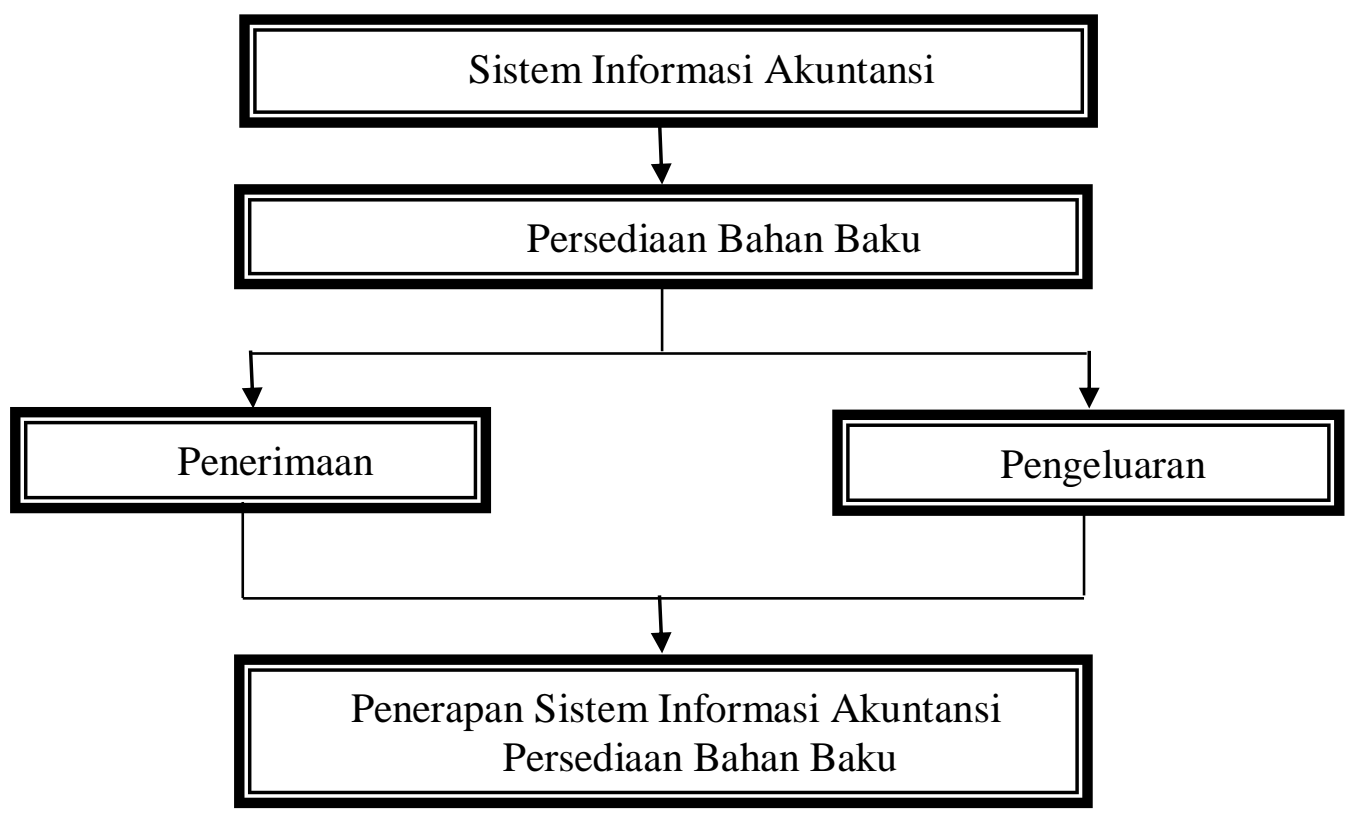




\section{METODE PENELITIAN}

Sugiyono (2018: 21) menjelaskan metode penelitian adalah cara ilmiah untuk mendapatkan data dengan tujuan dan kegunaan tertentu. Metode yang digunakan pada penelitian ini adalah metode kualitatif.

\section{Variabel Penelitian}

Sugiyono (2018:68) variabel penelitian adalah suatu atribut atau sifat atau nilai dari orang, objek, organisasi atau kegiatan yang mempunyai variasi tertentu yang ditetapkan oleh peneliti untuk dipelajari dan kemudian ditarik kesimpulannya. Adapun variabel yang digunakan dalam penelitian ini adalah sistem informasi akuntansi dan persediaan bahan baku.

\section{Populasi dan Sampel}

\section{Populasi}

Sugiyono (2018:136) populasi adalah keseluruhan elemen yang akan dijadikan wilayah generalisasi. Elemen populasi adalah keseluruhan subjek yang akan diukur yang merupakan unit yang akan diteliti. Populasi yang akan diteliti pada penelitiaan ini adalah Perediaan Bahan Baku Tahun 2017-2019.

2. Sampel

Sugiyono (2018:137) sampel adalah bagian dari jumlah karakteristik yang dimiliki oleh populasi tersebut. Sampel yang diambil dari populasi harus respresentative (mewakili).

Adapun sampel yang digunakan dalam penelitian ini adalah Sistem Informasi Akuntansi Persediaan Bahan Baku PT Pupuk Sriwidjaja Palembang (Persero) tahun 2017-2019.

\section{Sumber Data}

Adapun sumber data yang digunakan pada penelitian ini adalah:

1. Data Sekunder merupakan sumber yang tidak langsung memberikan data kepada pengumpul data, misalnya lewat orang lain atau lewat dokumen.

Adapun sumber data yang digunakan dalam penelitian ini adalah data sekunder berupa persediaan bahan baku pada PT Pupuk Sriwidjaja (Persero) Palembang.

\section{Teknik Pengumpulan Data}

Adapun teknik pengumpulan yang digunakan dalam penelitian ini adalah teknik studi kepustakaan, teknik observasi, dan teknik dokumentasi.

1. Studi Kepustakaan

Studi kepustakaan dengan mempelajari buku-buku, bacaan lain, atau literatur yang berkaitan dengan masalah yang diteliti. Pada tahap ini juga dilakukan pengkajiaan data yang yang dibutuhkan yaitu mengenai jenis data yang dibutuhkan, ketersediaan data, dan cara memperoleh data dan gambaran pengelolahan data. Tahap selanjutnya adalah penelitian pokok yang digunakan untuk mengumpulkan keseluruhan data yang dibutuhkan untuk menjawab persoalan penelitian dan memperkaya literatur untuk menunjang data kualitatif yang diperoleh (Arikunto, 2010:207).

\section{Observasi}

Teknik pengumpulan data dengan observasi (Sugiyono, 2018:457). 


\section{Dokumen}

Teknik pengumpulan data dengan dokumen adalah bisa berbentuk tulisan, gambar, atau karya-karya monumental dari seseorang (Sugiyono, 2018:476).

\section{Teknik Analisis Data}

Sugiyono (2018:414) mengungkapkan teknik analisis data ini berkenaan dengan perhitungan untuk menjawab rumusan masalah dan pengujian hipotesis yang diajukan.

Teknik yang digunakan dalam penelitian ini menggunakan teknik analisis deskriptif kualitatif dengan cara data dikumpulkan, disusun dan dianalisa sehingga memberikan keterangan yang jelas dan lengkap guna memecahkan masalah yang diteliti. Sesuai dengan perumusan masalah, jadi seluruh data yang berkaitan dengan sistem informasi akuntansi persediaan bahan baku yang akan dikumpulkan, disusun dan disesuaikan dengan teori yang ada berupa data yang berkaitan dengan pengamatan dan dokumentasi yang berkaitan dengan sistem informasi akuntansi persediaan bahan baku pada PT Pupuk Sriwidjaja Palembang.

\section{HASIL DAN PEMBAHASAN}

1) Hasil Penelitian

\section{Sistem Informasi Akuntansi Persediaan Bahan Baku pada PT Pupuk Sriwidjaja (Persero) Palembang}

Dalam penerapan sistem informasi akuntansi persediaan bahan baku pada PT Pupuk Sriwidjaja (Persero) Palembang . Kebijakan-kebijakan dalam sistem informasi akuntansi persediaan bahan baku yang diterapkan PT Pupuk Sriwidjaja (Persero) Palembang adalah sebagai berikut:

1. Sistem Pencatatan Persediaan Bahan Baku

Sistem pencatatan persediaan bahan baku pada PT Pupuk Sriwidjaja (Persero) Palembang menggunakan pencatatan mulai dari permintaan pengadan, penerimaan materialnya di gudang pusri, proses QC, sampai proses pengebonan.

2. Metode Penilaian Persediaan Bahan Baku

Metode penilaian persediaan bahan baku yang digunakan PT Pupuk Sriwdijaja (Persero) Palembang adalah metode Average Cost (metode rata-rata tertimbang) dimana untuk mendapatkan harga pokok perunit, maka persediaan awal serta pembelian-pembelian haruslah dijumlahkan dan jumlah himpunan harga pokok secara keseluruhan dibagi dengan jumlah himpunan unit persediaan secara keseluruhan.

3. Fasilitas Penyimpanan Persediaan Bahan Baku

Fasilitas penyimpanan persediaan bahan baku pada PT Pupuk Sriwidjaja (Persero) Palembang disimpan pada gudang. Fasilitas gudang indoor dengan belt conveyor (mesin untuk mendistribusikan bahan baku ke mesin produksi).

4. Deskripsi Sistem Informasi Akuntansi Persediaan PT Pupuk Sriwidjaja (Persero) Palembang.

Dalam sistem persediaan PT Pupuk Sriwidjaja (Persero) Palembang terdapat enam bagian utama yang dijelaskan yaitu Sumber Daya Manusia, Peralatan, Formulir, Catatan, Prosedur, dan Laporan. 


\section{Tabel Laporan Persediaan PT Pupuk Sriwidjaja (Persero) Palembang Tahun 2017}

\begin{tabular}{|c|c|c|l|l|l|l|}
\hline \multicolumn{2}{|l|}{ Periode Desember $\mathbf{1 3}$ (Audited) 2017 } & & & & \\
\hline & & & & & & \\
\hline ValA & Material & Material Description & Lokasi & To Date & Quantity & BUn \\
\hline & & & & & & \\
\hline F601 & 4000028 & PEWARNA:NPK SUBSIDI & Unit Produksi & 31.12 .2017 & 16.000 & KG \\
\hline F601 & 4001052 & ANTI-CAKING COMPOUND:LIQUID & Unit Produksi & 31.12 .2017 & 221.600 & KG \\
\hline F006 & 5000031 & SACK:NPK;15-15-15;SUB;50KG & Unit Produksi & 31.12 .2017 & 272.311 & EA \\
\hline F601 & 5000252 & BENANG JAHIT "MULTI FILAMENT" & Unit Produksi & 31.12 .2017 & 1.455 & KG \\
\hline F601 & 5000376 & KANTONG PUPUK NPK;25KG;NO FORMULA & Unit Produksi & 31.12 .2017 & 200.000 & EA \\
\hline F601 & 5000377 & KANTONG PUPUK NPK;25KG;12-12-17-2 & Unit Produksi & 31.12 .2017 & 200.000 & EA \\
\hline F601 & 5000378 & KANTONG PUPUK NPK;25KG;13-6-27-4+0.6B & Unit Produksi & 31.12 .2017 & 200.000 & EA \\
\hline F601 & 5000379 & KANTONG PUPUK NPK;25KG;15-15-15 & Unit Produksi & 31.12 .2017 & 135.750 & EA \\
\hline F601 & 5000380 & KARDUS PUPUK UREA;1KG & Unit Produksi & 31.12 .2017 & 230 & EA \\
\hline F601 & 5000382 & KARDUS PUPUK NPK;1KG & Unit Produksi & 31.12 .2017 & 1.250 & EA \\
\hline F601 & 5000395 & KANTONG PUPUK UREA;1KG & Unit Produksi & 31.12 .2017 & 2.900 & EA \\
\hline F601 & 5000396 & KANTONG PUPUK UREA;5KG & Unit Produksi & 31.12 .2017 & 570 & EA \\
\hline F601 & 5000397 & KANTONG PUPUK UREA;10KG & Unit Produksi & 31.12 .2017 & 318.400 & EA \\
\hline F601 & 5000398 & KANTONG PUPUK UREA;25KG & Unit Produksi & 31.12 .2017 & 743.950 & EA \\
\hline F601 & 5000399 & KANTONG PUPUK NPK;1KG;15-15-15 & Unit Produksi & 31.12 .2017 & 25.000 & EA \\
\hline F601 & 5000400 & KANTONG PUPUK NPK;5KG;15-15-15 & Unit Produksi & 31.12 .2017 & 15.000 & EA \\
\hline F601 & 5000401 & KANTONG PUPUK NPK;10KG;15-15-15 & Unit Produksi & 31.12 .2017 & 24.900 & EA \\
\hline F601 & 5000424 & SACK:UREA PRILL;NITREA;UPSUS;50KG & Unit Produksi & 31.12 .2017 & 30.000 & EA \\
\hline
\end{tabular}

Sumber: PT Pupuk Sriwidjaja Palembang (diolah 2020)

\section{Tabel Laporan persediaan PT Pupuk Sriwidjaja (Persero) Palembang Tahun 2018}

\begin{tabular}{|c|c|c|c|c|c|c|}
\hline \multicolumn{3}{|c|}{ Posisi Persediaan Bahan Baku Pupuk } & & & & \\
\hline \multicolumn{3}{|c|}{ Periode Desember 2018} & & & & \\
\hline ValA & Material & Material Description & Lokasi & To Date & Quantity & BUn \\
\hline & 1000017 & DAP:(NH4)2HPO4;GRANULAR;64\% & Unit Produksi & 31.12 .2018 & $4.580,457$ & TON \\
\hline & 1000030 & Urea PRL NS CRH & Unit Produksi & 31.12 .2018 & 618,671 & TON \\
\hline & 1000056 & AMMONIUM SULPHATE:ZA CRH;20.8\%N MIN & Unit Produksi & 31.12 .2018 & 736,050 & TON \\
\hline & 3000018 & KALIUM CHLORIDE:KCL;K2O 60\%MIN & Unit Produksi & 31.12 .2018 & $7.324,068$ & TON \\
\hline & 3000331 & DRILLING MUD:BROWN CLAY & Unit Produksi & 31.12 .2018 & $2.362,470$ & TON \\
\hline & 3000007 & BRUCITE:MGO 85\%;POWDER & Unit Produksi & 31.12 .2018 & 500,450 & TON \\
\hline & 3000027 & PHOSPHATE ROCK:P2O5 28,37\%;POWDER & Unit Produksi & 31.12 .2018 & $1.634,523$ & TON \\
\hline & 3000033 & $\begin{array}{c}\text { COATING OIL:PASTA;BROWNISH } \\
\text { YELLOWISH } \\
\end{array}$ & Unit Produksi & 31.12 .2018 & $35.066,770$ & $\mathrm{~L}$ \\
\hline & 3000036 & BORIC ACID,TECH:[B2O3];56\% WT & Unit Produksi & 31.12 .2018 & 77,893 & TON \\
\hline & 3000068 & MAGNESIUM CARBONATE:CaMg(C03)2;PWD & Unit Produksi & 31.12 .2018 & 49,411 & TON \\
\hline
\end{tabular}

\section{Sumber: PT Pupuk Sriwidjaja Palembang (diolah 2020)}




\section{Tabel Laporan persediaan PT Pupuk Sriwidjaja (Persero) Palembang Tahun 2019}

\begin{tabular}{|c|c|c|c|c|c|c|}
\hline \multicolumn{3}{|c|}{ Posisi Persediaan Bahan Baku Pupuk } & & & & \\
\hline \multicolumn{7}{|c|}{ Periode Desember 2019} \\
\hline ValA & Material & Material Description & Lokasi & To Date & Quantity & BUn \\
\hline F006 & 4000028 & PEWARNA:NPK SUBSIDI & Unit Produksi & 31.12 .2019 & $37.755,00$ & $\mathrm{KG}$ \\
\hline F601 & 4001052 & ANTI-CAKING COMPOUND:LIQUID & Unit Produksi & 31.12 .2019 & $133.100,00$ & KG \\
\hline F601 & 4001897 & COATING AGENT NPK:PASTE;OIL BASED & Unit Produksi & 31.12 .2019 & $43.935,17$ & KG \\
\hline F601 & 5000028 & SACK;NPK;NS;50KG & Unit Produksi & 31.12 .2019 & $583.971,00$ & EA \\
\hline F601 & 5000031 & SACK:NPK;15-15-15;SUB;50KG & Unit Produksi & 31.12 .2019 & $983.952,00$ & EA \\
\hline F601 & 5000252 & BENANG JAHIT "MULTI FILAMENT" & Unit Produksi & 31.12 .2019 & 200,00 & KG \\
\hline F601 & 5000376 & KANTONG PUPUK NPK;25KG;NO FORMULA & Unit Produksi & 31.12 .2019 & $199.990,00$ & EA \\
\hline F601 & 5000377 & KANTONG PUPUK NPK;25KG;12-12-17-2 & Unit Produksi & 31.12 .2019 & $297.495,00$ & EA \\
\hline F601 & 5000378 & KANTONG PUPUK NPK;25KG;13-6-27-4+0.6B & Unit Produksi & 31.12 .2019 & $278.440,00$ & EA \\
\hline F601 & 5000379 & KANTONG PUPUK NPK;25KG;15-15-15 & Unit Produksi & 31.12 .2019 & $823.145,00$ & EA \\
\hline F601 & 5000399 & KANTONG PUPUK NPK;1KG;15-15-15 & Unit Produksi & 31.12 .2019 & $161.050,00$ & EA \\
\hline F601 & 5000400 & KANTONG PUPUK NPK;5KG;15-15-15 & Unit Produksi & 31.12 .2019 & $86.885,00$ & EA \\
\hline F601 & 5000401 & KANTONG PUPUK NPK;10KG;15-15-15 & Unit Produksi & 31.12 .2019 & $265.390,00$ & EA \\
\hline F601 & 5000604 & KANTONG NPK;1KG;12-12-17-2 & Unit Produksi & 31.12 .2019 & $89.250,00$ & EA \\
\hline F601 & 5000605 & KANTONG NPK;5KG;12-12-17-2 & Unit Produksi & 31.12 .2019 & $97.450,00$ & EA \\
\hline F601 & 5000606 & KANTONG NPK;1KG;13-6-27-4+0.65B & Unit Produksi & 31.12 .2019 & $87.400,00$ & EA \\
\hline F601 & 5000607 & KANTONG NPK;5KG;13-6-27-4+0.65B & Unit Produksi & 31.12 .2019 & $96.950,00$ & EA \\
\hline F601 & 5000608 & KANTONG NPK LAMINASI;25KG;15-15-15 & Unit Produksi & 31.12 .2019 & $63.940,00$ & EA \\
\hline F601 & 5000651 & KANTONG NPK LAMINASI;25KG;16-16-16 & Unit Produksi & 31.12 .2019 & $99.996,00$ & EA \\
\hline F601 & 5000654 & KARDUS PUPUK RETAIL;1KG & Unit Produksi & 31.12 .2019 & $3.550,00$ & EA \\
\hline
\end{tabular}

Sumber: PT Pupuk Sriwidjaja Palembang (diolah 2020)

\section{2) Pembahasan}

Sistem informasi akuntansi persediaan bahan baku perusahaan secara keseluruhan diukur berdasarkan laporan persediaan bahan baku persediaan bahan baku selama 3 tahun terakhir. Berikut ini perkembangan tiga tahun terakhir yang dapat memberikan gambaran secara keseluruhan tabel dibawah ini:

Dari pembahasan terkait persediaan bahan baku pada tahun 2017-2019 adapun perbandingan persediaan yang dikeluarkan oleh PT Pupuk Sriwidjaja (Persero) Palembang diantaranya adalah pada tahun 2017 jumlah keseluruhan bahan dari unit produksi sekitar 2.409.316 di tahun 2017 dengan rata-rata: 1.33850888889E5. Dari hasil ini dapat dipastikan pupuk NPK yang dihasilkan oleh PT Pusri sebesar 89.520 TON.

Sedangkan di tahun 2018 bahan baku yang dikeluarkan oleh PT Pupuk Sriwidjaja (Persero) Palembang dengan total keseluruhan bahan baku yang dibutuhkan sebesar 2.4053E7 dengan rata-rata 1.2026E6. pada tahun 2018 ini bahan baku yang digunakan PT Pusri lebih banyak ke bagian persediaan bahan inti untuk pupuk tersebut. Dari hasil tersebut dapat dipastikan pada tahun 2018 PT Pupuk Sriwidjaja (Persero) Palembang bisa menghasilkan Pupuk NPK sebanyak 104.578 TON.

Jika dibandingkan dengan tahun 2017 adapun kenaikan produksi Pupuk NPK sebesar 15.058 TON. 
Pada tahun 2019 bahan baku yang dikeluarkan oleh PT Pupuk Sriwidjaja (Persero) Palembang dengan total keseluruhan sebesar 1.0144E8 dengan sedikit pengurangan bahan baku, dengan rata-rata 2.5361E6.

Yang mana pada tahun 2019 ini bahan baku yang digunakan hampir sama seperti pada tahun 2017, namun ada penambahan dibeberapa bahan. Dengan adanya penambahan itu penghasilan Pupuk NPK pada tahun 2019 ini lebih besar dari tahun 2017. Adapun produksi Pupuk NPK pada tahun 2019 ini sebanyak 103.338 TON. Mengalami kenaikan sebesar 13.818 TON dari tahun 2017. Dan jika dibandingkan dengan tahun 2018 di tahun 2019 ini mengalami penurunan produksi sebesar 1.240 TON.

\section{E. KESIMPULAN DAN SARAN}

1) Kesimpulan

Dari hasil penelitian dan pembahasan mengenai sistem informasi akuntansi persediaan bahan baku pada PT Pupuk Sriwidjaja (Persero) Palembang, maka dapat ditarik kesimpulan sebagai berikut:

a. Dalam hal persediaan sesuai prosedur yang diperlukan,yaitu: proses pemesanan material (menggunakan modul procurement), penerimaan material dari vendor (menggunakan modul warehouse management), pemakaian material oleh user / pabrik (menggunakan modul Production Planing), pengecekan biaya yang terjadi akibat pemakaian bahan baku oleh akuntansi (menggunakan modul finance), dan lain-lain. Jadi hampir seluruh karyawan di PT Pusri merupakan user (orang-orang yang memakai sistem) SAP dan mereka memahami tugas, wewenang,tanggung jawab mereka masing-masing sesuai dengan kecakapan, keahlian dan kemapuan mereka untuk mengolah data dengan sistem SAP. SAP (System Application and Product) itu sendiri adalah suatu software yang dikembangkan untuk mendukung suatu organisasi atau perusahaan dalam menjalannya kegiatan operasionalnya secara lebih efisien dan efektif. SAP juga merupakan software Enterprise Resources Palnning (ERP), yaitu suatu tools IT dan manajemen untuk membantu perusahaan merencanakan dan melakukan berbagai aktivitas sehari-hari. Jadi terlihat sangat jelas bahwa SAP itu merupakan perangkat komputer yang berperan banyak diantara nya adalah sebagai pengolahan data, pengarsipan (penyimpanan) data, mengontrol penjualan, produksi, manajemen persediaan, hingga manajemen SDM.

b. Dari batasan masalah yang diteliti dapat ditarik kesimpulan bahwa posisi persediaan bahan baku yang ada PT Pupuk Sriwidjaja (Persero) Palembang merupakan posisi stok terakhir di 31 Desember setelah ada penerimaan dan pengeluaran selama 1 tahun.

\section{2) Saran}

Berdasarkan hasil penelitian dan kesimpulan yang telah diuraikan, maka peneliti dapat memberikan saran sebagai berikut:

a. PT Pupuk Sriwidjaja (Persero) Palembang mengkoreksi pengawasan atas setiap pencatatan dan fisik persediaan yang tersedia secara berkala.

b. Bagi pihak akuntansi biaya di PT Pupuk Sriwidjaja (Persero) Palembang kedepannya harus memegang atau memiliki data tentang biaya pengadaan untuk dapat menggunakan metode EOQ dalam melakukan pembelian persediaan. Karena dengan metode EOQ perusahaan dapat melakukan 
penghematan biaya persediaan sehingga penghematan yang diperoleh pabrik dapat dialokasi untuk kebutuhan lain.

\section{DAFTAR PUSTAKA}

Achmad Jawaahirul Mustofa, dkk. 2015. Analisis Sistem Informasi Akuntansi Persedian Bahan Baku dalam Kelancaran Proses Produksi (Study Kasus Pada UD. Bintang Terang Surabaya). jurnal akuntansi, 1 (2).

http:// www.sikp.pusri.co.id

Ladewi, Y. 2019. Sistem Informasi Akuntansi I (teori dan praktik). Palembang: Lembaga Penerbit Fakultas Ekonomi Universitas Muhammadiyah Palembang.

Marshall B. Romney, Paul. 2015. Sistem Informasi Akuntansi Edisi 13. Indonesia: Salemba Empat.

Poputra, P. L. 2016. Peranan pengendalian internal persediaan barang dagang dalam menunjang efektivitas pengelolaan pada studi kasus Pt. Samsung Elektronics Indonesia cabang Manado. Accountabilityi, 5.

Rangkuti, F. 2018. Manajemen persediaan aplikasi di bidang bisnis. Jakarta: PT RajaGrafindo Persada.

Sugiyono. 2018. Metode penelitian bisnis. Bandung: Alfabeta. 